\title{
Hva er etablert behandling?
}

Hver dag introduseres nye diagnostiske og terapeutiske metoder, tester og prosedyrer. En hovedregel er at metoder, instrumenter og teknikker som ikke er ferdig utprøvd i kliniske studier, er å anse som eksperimentelle. Men når har vi kunnskap nok til å definere en metode som «etablert» og dermed klar til å tilbys alle?

Vegard Bruun Wyller og medarbeidere presenterer i dette nummer av Tidsskriftet en artikkel om kateterbasert innsetting av kunstig pulmonalklaff hos barn og unge med medfødt hjertefeil (1). De beskriver ikke et forskningsprosjekt, de presenterer en kasuistisk pasientserie med de ti første som ble behandlet med denne nye metoden ved Rikshospitalet i perioden 2007-09. Prosedyren var brukt ved utenlandske sentre mer enn 1600 ganger før dette (1). Men det finnes ingen randomiserte studier med metoden. Altså har alle andre «utprøvninger» foregått på samme måte som ved Rikshospitalet, nemlig ved at man satte i gang uten å gjennomføre en klinisk studie der man kunne sammenlikne den nye metoden med den etablerte (åpen kirurgi). Forfatterne forklarer at fagmiljøet har betraktet innsetting av kunstig pulmonalklaff som et nytt klinisk tilbud, ikke som eksperimentell behandling. Dermed mente de at skriftlig samtykke fra pasientene eller godkjenning fra regional komité for medisinsk forskningsetikk (REK) ikke var nødvendig da denne behandlingen ble innført (1). Stein A. Evensen, som har skrevet en ledsagende leder til artikkelen, er uenig: Etter hans mening må kateterbasert innsetting av kunstig pulmonalklaff klart defineres som utprøvende behandling, altså forskning $(2,3)$.

Innføring av ny diagnostikk og behandling uten forutgående kliniske studier har vært det vanlige innen medisinen. Kontrollerte studier er relativt nytt. De aller fleste store medisinske nyvinninger, for eksempel antibiotikabehandling eller organtransplantasjon, har vært innført uten at det har vært gjennomført studier med kontrollgruppe. Utvilsomt har dette ofte gitt gevinst for berørte pasienter og for samfunnet. Men nye metoder medfører naturligvis også risiko for potensielt alvorlige bivirkninger og komplikasjoner. Det vil også lettere oppstå rapporteringsskjevheter, og det kan bli vanskelig å bedømme nytten når man ikke har noe å sammenlikne med. Det finnes noen få nye behandlinger der man med bakgrunn i kunnskap generert utenom kliniske studier med stor sannsynlighet kan si at det nye er bedre enn det man hadde før. I disse tilfellene vil man kunne argumentere for at kliniske studier med kontrollgruppe er uetisk eller i alle fall svært vanskelige å gjennomføre (4). Behandling av visse former av infantilt hemangiom med propanolol $(5,6)$ og perkutan kateterbasert innsetting av kunstig pulmonalklaff hos barn og ungdom med medfødt hjertefeil kan etter redaksjonens vurdering være to slike metoder.

Hvorvidt en metode defineres som etablert eller eksperimentell, får store praktiske konsekvenser for pasienter og leger, utstyrsprodusenter og samfunnet. Dette er ingen teoretisk skrivebordsdiskusjon som kan avfeies som formalia. Etablert behandling blir lettere tilgjengelig. Det er en klar fordel for pasientene. Men ved eksperimentell behandling har de langt bedre beskyttelse, de har krav på mer informasjon og har flere rettigheter om det skulle oppstå komplikasjoner. For legene er det atskillig mindre arbeidskrevende hvis en metode defineres som etablert. Samtidig er vi selvfølgelig legeetisk forpliktet til å sette pasientens interesser foran det vi selv kan oppfatte som unødig «heft og byråkrati». Alle medlemmer av Verdens legeforening - dermed de aller fleste norske leger - er bundet av Helsinkideklarasjonen, som bl.a. regulerer klinisk forskning og forholdet mellom forskning og pasientbehandling $(7,8)$. For utstyrsprodusentene er det en soleklar fordel å få en behandling definert som etablert. Så lenge det dreier deg om forskning og utvikling, må de i all hovedsak dekke kostnadene selv. I det øyeblikk en metode kan defineres som etablert, vil det offentlige ta regningen. Den blir ofte svært stor, og produsentenes inntjening tilsvarende. I tillegg er det i en klinisk studie fare for at det viser seg at den nye metoden ikke er bedre enn den gamle. Hvis man ikke utfører slike studier, vil man aldri finne ut om den nye metoden virkelig er bedre. Produsenten har derfor økonomisk interesse av å få definert noe som «etablert».

Hva er så best for samfunnet? I vårt land, hvor det offentlige fortsatt betaler det aller meste av helsetjenestene (og nesten alt av avansert og dyr diagnostikk og behandling), skulle man tro at det åpenbart var i samfunnets interesse at en behandling var best mulig utprøvd og testet før den inngikk som en del av det fellesskapet betaler. Men i praksis er det mer komplisert fordi god forskning koster, og den regningen har ikke Finansdepartementet særlig lyst på, selv om det etter alt å dømme vil vise seg lønnsomt på sikt. Legemiddelindustrien betaler for det aller meste av legemiddelutprøvningen fordi dette området er nøye regulert. For annet utstyr og andre diagnostiske og terapeutiske metoder finnes ikke samme dokumentasjonskrav. Produsentenes betalingsvilje blir da naturligvis ikke like stor.

Det paradoksale er at det offentlige i dag betaler for behandling med nye metoder - såfremt det skjer utenom kliniske studier. Refusjonstakster kan brukes for nye metoder på lik linje med velprøvde og etablerte så lenge metodene ikke er definert som eksperimentelle. Eksperimentell behandling må dekkes av små forskningsbudsjetter. Dette setter leger og kliniske forskere som er interessert i å ta i bruk lovende, ikke ferdig utprøvde metoder, i en svært vanskelig situasjon. Veldesignede kliniske studier koster penger og ressurser som i dag ikke er på plass. Bedre incentiver for kliniske studier vil ikke bare generere mer kunnskap, men også på sikt kunne spare vårt samfunn for store kostnader - fordi det vil vise seg at mange dyre metoder som i dag innføres uten kliniske studier, ikke er bedre enn de billigere man brukte før.

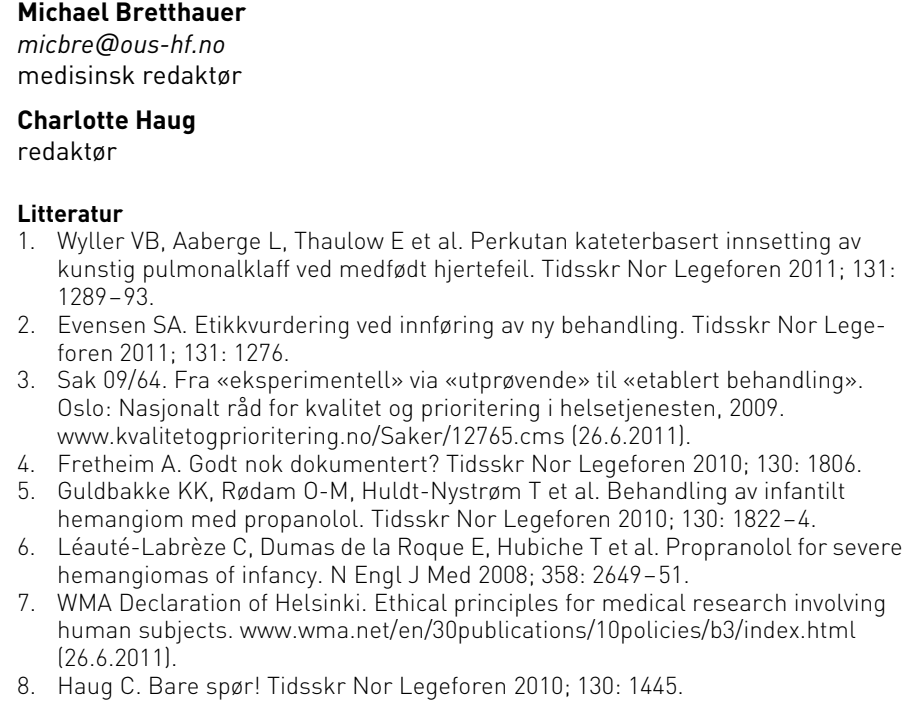

2. Evensen SA. Etikkvurdering ved innføring av ny behandling. Tidsskr Nor Legeforen 2011; 131: 1276.

3. Sak 09/64. Fra «eksperimentell» via «utprøvende» til «etablert behandling». Oslo: Nasjonalt råd for kvalitet og prioritering i helsetjenesten, 2009. www.kvalitetogprioritering.no/Saker/12765.cms (26.6.2011).

4. Fretheim A. Godt nok dokumentert? Tidsskr Nor Legeforen 2010; 130: 1806.

5. Guldbakke KK, Rødam 0-M, Huldt-Nystrøm T et al. Behandling av infantilt hemangiom med propanolol. Tidsskr Nor Legeforen 2010; 130: 1822-4.

6. Léauté-Labrèze C, Dumas de la Roque E, Hubiche T et al. Propranolol for severe hemangiomas of infancy. N Engl J Med 2008; 358: 2649-51.

7. WMA Declaration of Helsinki. Ethical principles for medical research involving human subjects. www.wma.net/en/30publications/10policies/b3/index.html (26.6.2011).

8. Haug C. Bare spør! Tidsskr Nor Legeforen 2010; 130: 1445 